\title{
Yeast extract plus blood plasma in diets for piglets from 36 to 60 days old
}

\author{
Extrato de levedura associado ao plasma sanguíneo sobre \\ o desempenho de leitões dos 36 aos 60 dias
}

\section{Cinthia Maria Carlos Pereira ${ }^{\mathrm{I}}$ Juarez Lopes Donzele ${ }^{\mathrm{II}}$ Rita Flávia Miranda de Oliveira Donzele ${ }^{\mathrm{II}}$ Charles Kiefer ${ }^{\text {III }}$ Verônica Maria Pereira Bernardino ${ }^{\text {IV }}$ Eric Marcio Balbino ${ }^{\text {II }}$ Gabriel Cipriano Rocha ${ }^{I^{*}}$}

\section{ABSTRACT}

To evaluate inclusion levels and residual effects of diets containing yeast extract (YE) plus blood plasma (BP) on the performance of 36 to 60-days old piglets, 105 piglets were used $(8.75 \pm 0.72 \mathrm{~kg})$, and they were distributed under a randomized block experimental design with five treatments (control - $2.0 \%$ $B P ; 1.0 \%$ BP plus $0.0,1.0,2.0$, or $3.0 \% Y E$ ), seven repetitions, and three animals per experimental unit. Piglets were given experimental diets from 36 to 49 days of age. From 50 to 60 day of age, all piglets received the same diet. No effects from treatments $(P>0.10)$ were observed on the performance variables from 36 to 49 day of age. From 50 to 60 day of age, an effect was observed from $Y E$ levels on the daily feed consumption $(P<0.03)$, daily weight gain $(p<0.01)$, and final weight $(P<0.06)$, which increased quadratically up to $1.67,1.67$, and $1.55 \%$ YE levels, respectively. Piglets which were fed with the diet containing $1.0 \% \mathrm{BP}+2.0 \%$ $Y E$ were observed to have better feed conversion ratios $(P<0.01)$ as compared to the control diet $(2.0 \% \mathrm{BP})$. As it provides a better residual effect, the inclusion of $1.67 \%$ yeast extract may replace $50 \%$ of blood plasma in 36 to 49-days old piglet diets.

Key words: performance, residual effect, nutrition, swines.

\section{RESUMO}

Para avaliar níveis de inclusão e o efeito residual de dietas contendo extrato de levedura (ExL) associado ao plasma sanguíneo (PS) sobre o desempenho de leitões dos 36 aos 60 dias, foram utilizados 105 leitões $(8,75 \pm 0,72 \mathrm{~kg})$, distribuídos em delineamento experimental de blocos ao acaso com cinco tratamentos (controle-2,0\% de PS; 1,0\% PS, associado ao 0; 1,0; 2,0 ou 3,0\% de ExL), sete repetições e três animais por unidade experimental. As dietas experimentais foram fornecidas dos 36 aos 49 dias e, dos 50 aos 60 dias de idade, os animais passaram a receber dieta única para avaliar o efeito residual dos tratamentos experimentais. Não foram observados efeitos dos tratamentos $(P>0,10)$ sobre as variáveis de desempenho dos 36 aos 49 dias de idade. Dos 50 aos 60 dias de idade, houve efeito dos níveis de ExL sobre o consumo de ração diário $(P<0,03)$, ganho de peso diário $(P<0,01)$ e peso final $(P<0,06)$ que aumentaram de forma quadrática até os niveis de 1,67, 1,67 e 1,55\% de ExL, respectivamente. Leitões alimentados com a dieta contendo $1,0 \%$ de $P S+2,0 \%$ de ExL apresentaram melhor $(P<0,01)$ conversão alimentar em relação à dieta controle $(2 \%$ de $P S)$. Por proporcionar melhor efeito residual, a inclusão de $1,67 \%$ de extrato de levedura pode substituir $50 \%$ do plasma sanguíneo na dieta de leitões dos 36 aos 49 dias de idade.

Palavras-chave: desempenho, efeito residual, nutrição, suínos

\section{INTRODUCTION}

The post-weaning period may be considered critical for piglets, once they are submitted to several stress situations (SOBESTIANSKY et al., 2001) such as environmental changes (new facilities and/ or environmental temperatures), removal from the sow, replacement of liquid with solid diets, and social tensions arising from getting animal grouped back after being separated (FERREIRA et al., 2001). Thus, aiming to minimize the stress which is observed in this initial phase, and to avoid sudden feed consumption reductions, studies have been developed in order to seek feeds which may be added to piglet diets in

\footnotetext{
'Departamento de Ciências Agrárias e Ambientais, Universidade Estadual de Santa Cruz (UESC), Ilhéus, BA, Brasil

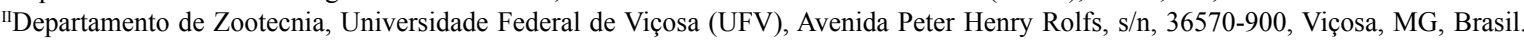
E-mail: gcrocha@ufv.br. *Corresponding author

IIIFaculdade de Medicina Veterinária e Zootecnia, Universidade Federal de Mato Grosso do Sul (UFMS), Campo Grande, MS, Brasil

${ }^{\text {IV }}$ Departamento de Zootecnia, Universidade Federal de Lavras (UFLA), Lavras, MG, Brasil.
} 
their post-weaning period. Use of those feeds intends to minimize the negative effects which generally take place on the performance of animals during that period. Among those feeds, we can mention blood plasma (BP) and yeast extract (YE).

Blood Plasma which is rich in immunoglobulins and glutamic acid, and it has been used in piglet diets during the first days after they are weaned, yielding excellent results in regards to feed consumption, due to its excellent palatability. However, studies (TOUCHETTE et al., 1996; BARBOSA et al., 2007) showed that the beneficial effect from BP on animal performance may better observed when it is fed for longer periods. Therefore, BP removal from piglet diets can lead to lower feed intake and, consequently, poorer performance.

Yeast extract, which is obtained from the internal contents of cells from specific strains of Saccharomyces cerevisae 1026 yeast, has been used in post-weaning diets associated with BP to improve intestinal mucosa and performance during the first days after weaning (CARLSON et al., 2005; RIGUEIRA et al., 2013). However, more studies need to be conducted in order to evaluate whether said effects linger on subsequent phases and whether adding YE to BP provides a residual effect on the performance of piglets.

Therefore, this study aimed to evaluate the effect from the use of yeast extract plus blood plasma in 36 to 49-days old piglets, as well as the possible residual effect on the performances of 50 to 60-days old piglets.

\section{MATERIALS AND METHODS}

One hundred and five 36 to 60-days old piglets from Large White $\mathrm{x}$ Landrace lineage were used. From weaning ( 21 days) to 35 days of age, piglets were fed with a single diet. With 36 days of age, animals with initial average weight of $8.75 \pm 0.72 \mathrm{~kg}$ were distributed under a randomized block experimental design with five treatments (control - 2.0\% BP; 1.0\% BP plus 0.0. 1.0, 2.0, or $3.0 \% \mathrm{YE}$ ), seven repetitions, and three animals per experimental unit. The blocks took into account the weight of animals with 36 days of age. In order to evaluate the residual effect from the experimental diets (provided from 36 to 49 days of age), animals received a single diet from 50 to 60 days of age.

Experimental diets contained the same levels of energy and amino acids, and they were prepared so as to meet the animals' nutritional requirements, as preconized by ROSTAGNO et al. (2005). Percentage and nutrient compositions of experimental diets that were used within the period from 36 to 49 days are presented in table 1 . From 50 to 60 days of age, all piglets received the same diet, which was based on corn and soy bean meal, with $3,280 \mathrm{kcal} \mathrm{kg}^{-1}$ metabolizable energy, $20.8 \%$ crude protein, $1.16 \%$ digestible lysine, $0.72 \% \mathrm{Ca}$, and $0.40 \%$ phosphorus available. Nutrient compositions of AP $920^{\circledR}$ blood plasma and NuPro ${ }^{\circledR}$ yeast extract are presented in table 2 .

Animals were confined in suspended cages with wooden floors, semi-automatic feeders, and nipple drinkers, inside a masonry warehouse with concrete floor, wooden ceiling, and ceramic roof tiles. Thermal variations inside the room were recorded daily at 4 p.m., through a maximum-minimum thermometer. Water and feed were provided ad libitum during the experimental period.

To determine their performance, animals were weighed at the beginning and at the end of each experimental phase in order to have their average daily gain (ADG) estimated. Feed leftovers on the floor were collected daily, and their amounts were summed to feed leftover from the feeders at the end of the experimental period in order to estimate their average daily feed intake (ADFI) and feed conversion ratio (FC).

Performance variables were statistically analyzed through Sistema de Análises Estatísticas e Genéticas (SAEG) software, which was developed by UNIVERSIDADE FEDERAL DE VIÇOSA (2007). The data were submitted to analysis of variance. Averages from the diets containing different YE levels were submitted to regression analysis. Additionally, the averages of each YE level that was associated with $\mathrm{BP}$ were compared to the average from the control diet $(2.0 \% \mathrm{BP})$, for each period (from 36 to 49 and from 50 to 60 days of age), through contrast analysis. A $10 \%$ significance level was used for all tests performed.

\section{RESULTS AND DISCUSSION}

The temperatures recorded by the maximum-minimum thermometer inside the shed during the experimental period remained, respectively, between $26.1 \pm 1.01^{\circ} \mathrm{C}$ and $29.8 \pm 1.32^{\circ} \mathrm{C}$. Considering that the average minimum temperature recorded during the experimental period was above the optimal temperature range $\left(18.0\right.$ to $\left.26.0^{\circ} \mathrm{C}\right)$ that is proposed for 14 to 40-days old piglets (FERREIRA, 2005), it can be inferred that piglets were raised in a thermoneutral environment.

Yeast extract levels did not influence $(\mathrm{P}>0.10)$ piglets weight at 49 days (Table 3 ). There was no significant effect of YE addition to 
Table 1 - Percentages and nutritional compositions of the experimental diets for piglets from 36 to 49 days old.

\begin{tabular}{|c|c|c|c|c|c|}
\hline Item $(\%)$ & $2.0 \% \mathrm{BP}$ & $1.0 \% \mathrm{BP}+0.0 \% \mathrm{YE}$ & $1.0 \% \mathrm{BP}+1.0 \% \mathrm{YE}$ & $1.0 \% \mathrm{BP}+2.0 \% \mathrm{YE}$ & $1.0 \% \mathrm{BP}+3.0 \% \mathrm{YE}$ \\
\hline Corn & 50.57 & 51.10 & 50.18 & 49.11 & 47.94 \\
\hline Dried whey & 8.57 & 8.57 & 8.57 & 8.57 & 8.57 \\
\hline Extruded soybean & 21.28 & 21.28 & 21.28 & 21.39 & 21.50 \\
\hline Soybean meal $45 \%$ & 14.00 & 14.00 & 14.00 & 14.00 & 14.00 \\
\hline Blood plasma & 2.00 & 1.00 & 1.00 & 1.00 & 1.00 \\
\hline Yeast extract & 0.00 & 0.00 & 1.00 & 2.00 & 3.00 \\
\hline Soybeal oil & 0.00 & 0.20 & 0.20 & 0.22 & 0.33 \\
\hline Dicalcium phosphate & 1.67 & 1.76 & 1.70 & 1.64 & 1.57 \\
\hline Limestone & 0.73 & 0.68 & 0.72 & 0.75 & 0.79 \\
\hline Salt & 0.37 & 0.42 & 0.37 & 0.33 & 0.29 \\
\hline L-lysine $\mathrm{HCl}$ & 0.29 & 0.37 & 0.37 & 0.37 & 0.37 \\
\hline DL-methionine & 0.14 & 0.16 & 0.16 & 0.16 & 0.17 \\
\hline L-threonine & 0.07 & 0.11 & 0.11 & 0.11 & 0.11 \\
\hline L-tryptophan & 0.01 & 0.01 & 0.01 & 0.01 & 0.01 \\
\hline L-valine & 0.00 & 0.03 & 0.03 & 0.04 & 0.04 \\
\hline L-isoleucine & 0.00 & 0.01 & 0.000 & 0.000 & 0.01 \\
\hline Vitamin $^{1}$ & 0.12 & 0.12 & 0.12 & 0.12 & 0.12 \\
\hline Mineral $^{2}$ & 0.08 & 0.08 & 0.08 & 0.08 & 0.08 \\
\hline Colistin Sulfate $10 \%$ & 0.10 & 0.10 & 0.10 & 0.10 & 0.10 \\
\hline $\mathrm{ME}\left(\mathrm{kcal} \mathrm{kg}^{-1}\right)$ & 3,400 & 3,400 & 3,400 & 3,400 & 3,400 \\
\hline Crude protein (\%) & 21.57 & 20.95 & 21.38 & 21.83 & 22.29 \\
\hline Digestible Lysine (\%) & 1.30 & 1.30 & 1.30 & 1.30 & 1.30 \\
\hline Digestible met + cys $(\%)$ & 0.73 & 0.73 & 0.73 & 0.73 & 0.73 \\
\hline Digestible threonine (\%) & 0.82 & 0.82 & 0.82 & 0.82 & 0.82 \\
\hline Digestible tryptophan (\%) & 0.22 & 0.22 & 0.22 & 0.22 & 0.22 \\
\hline Digestible valine (\%) & 0.90 & 0.90 & 0.90 & 0.90 & 0.90 \\
\hline Digestible isoleucine (\%) & 0.73 & 0.73 & 0.73 & 0.73 & 0.73 \\
\hline Lactose (\%) & 6.00 & 6.00 & 6.00 & 6.00 & 6.00 \\
\hline Calcium (\%) & 0.85 & 0.85 & 0.85 & 0.85 & 0.85 \\
\hline Available phosphuros (\%) & 0.50 & 0.50 & 0.50 & 0.50 & 0.50 \\
\hline
\end{tabular}

BP - blood plasma YE - yeast extract. ${ }^{1}$ Content per kg of feed: $12.000 \mathrm{IU}$ - vit A-; 2,250IU - vit. D3; 27mg - vit E; 3mg - vit K; $2.25 \mathrm{mg}$ thiamine; $6 \mathrm{mg}$ - riboflavin; $2.25 \mathrm{mg}$ - pyridoxine; $27 \mathrm{mcg}$ - vit B12; 400mcg - folic acid; $150 \mathrm{mcg}$ - biotin; $22.5 \mathrm{mg}$ - pantothenic acid; $45 \mathrm{mg}$ niacin; $300 \mathrm{mcg}-\mathrm{Se} ;{ }^{2}$ Content per kg of feed: $100 \mathrm{mg}$ iron; $100 \mathrm{mg}$ zinc; $10 \mathrm{mg}$ copper; $40 \mathrm{mg}$ manganese; $1.5 \mathrm{mg}$ iodine; $1 \mathrm{mg}$ cobalt.

diets, regardless of the levels used, as compared to the control diet $(2.0 \% \mathrm{BP})$ on piglets' weight at 49 days. There was no effect $(\mathrm{P}>0.10)$ of $\mathrm{YE}$ levels on the ADFI of piglets from 36 to 49 days. Likewise, when the ADFI of piglets fed the control diet was compared with animals which received diets containing different YE levels, no differences were found $(\mathrm{P}>0.10)$. Studies such as the one by RIGUEIRA et al. (2013) have not reported significant differences regarding the ADFI of 7 to 49-days old fed diets containing BP $(2.0 \%)$ or BP plus YE (1.0: $1.0 \%$ ). However, CARLSON et al. (2005) reported improved ADFI for 34 to 47-days old piglets, by adding $2.5 \% \mathrm{YE}$ alone in their diet, as compared to animals fed with the control diet $(0.0 \%)$.
According to COFFEY \& CROMWELL (1995) and ROSSI et al. (2007), the beneficial effects from $\mathrm{BP}$ and $\mathrm{YE}$, respectively, on ADFI, is expected in situations in which piglets are submitted to immunological challenges. Considering that facilities were properly washed, disinfected, and sealed thereafter, prior to the execution of this study, and that growth promoters were added to experimental diets, it can be inferred that animals may have been submitted to low immunological challenges, which may either justify the lack of ADFI variation between treatments.

Yeast extract levels did not influence ( $P>0.10) 36$ to 49-days old piglets' ADG. This result differs from the one that was obtained by CARLSON et al. (2005) who observed improved ADG for piglets 
Table 2 - Nutritional composition of blood plasma AP $920^{\circledR}$ and yeast extract NuPro ${ }^{\circledR}$.

\begin{tabular}{lcc}
\hline Nutrients & Blood plasma AP 920 $^{\circledR 1}$ & Yeast extract NuPro \\
\hline Metabolizable energy $\left(\mathrm{Kcal} \mathrm{kg}^{-1}\right)$ & 3,906 & 3,314 \\
Crude protein (\%) & 78.00 & 43.70 \\
Calcium (\%) & 0.15 & 0.02 \\
Available phosphorus (\%) & 1.30 & 1.20 \\
Sodium (\%) & 2.20 & 0.27 \\
Potassium (\%) & 0.30 & 1.15 \\
Lysine (\%) & 6.80 & 2.65 \\
Methionine (\%) & 0.70 & 0.63 \\
Threonine (\%) & 4.80 & 1.60 \\
Tryptophan (\%) & 1.40 & 0.34 \\
Valine (\%) & 5.30 & 2.15 \\
Isoleucine (\%) & 2.90 & 1.64 \\
Glutamic acid (\%) & 11.70 & 4.98 \\
Nucleic acid (\%) & - & $5.20-6.60$ \\
Inositol (g kg $\left.{ }^{-1}\right)$ & - & 5.83 \\
\hline
\end{tabular}

${ }^{1}$ APC AnLGlCompany. ${ }^{2}$ Alltech.

by adding $2.5 \% \mathrm{YE}$ in the diets. In the present study no differences were found $(\mathrm{P}>0.10)$ for the ADG of animals which received diet containing $2.0 \% \mathrm{BP}$ as compared to those which were fed with the YE diets. This result is in agreement with RIGUEIRA et al. (2013) who have not found ADG variation when comparing diets containing $\mathrm{BP}(2.0 \%)$ and $\mathrm{BP}$ plus YE $(1.0 ; 1.0 \%)$. Low exposure of animals to the immunological challenge may have contributed for the lack of positive effects from $\mathrm{BP}$ and $\mathrm{YE}$ on $\mathrm{ADG}$ in this study.

No effects $(\mathrm{P}>0.10)$ were observed from $\mathrm{YE}$ levels on the FC of piglets. Similarly, no differences were found $(\mathrm{P}>0.10)$ for the $\mathrm{FC}$ of animals which received the diet containing $2.0 \% \mathrm{BP}$ as compared to those which were fed with the YE diets. In the present study, the absence of effect from YE levels on the FC is consistent with results of ADFI and ADG. Some authors reported improved FC for piglet fed YE due to the lower ADFI associated with similar ADG (de ANDRADE et al., 2011; HU et al., 2014). The lower ADFI of piglets fed with YE have been attributed to its lower palatability. However, in the present study YE did not affect piglets ADFI and also did not affect FC.

The divergence of performance results between studies may be attributed to YE processing procedures (TRCKOVA et al., 2014). Different production and drying process may affect the quality of the yeast and its products regarding the composition of amino acids and peptides (THANISSERY et al., 2010).

A quadratic effect $(\mathrm{P}<0.06)$ was found for YE levels on the final weight of 60 -days old piglets, which has improved up to the estimated level of $1.55 \%$ YE (Table 3). No differences were observed $(\mathrm{P}>0.10)$ on final weights, when YE levels were compared with the control diet.

A quadratic effect $(\mathrm{P}<0.03)$ was found for YE levels on the ADFI of 50 to 60 -days old piglets, which has improved up to the estimated level of $1.67 \%$ YE. No differences were observed $(\mathrm{P}>0.10)$ for ADFI in that phase, when diets containing BP plus YE were compared to control group (2.0\% BP). Such result was similar to the one reported by RIGUEIRA et al. (2013), who have not found a residual effect on the ADFI 7 to 63-days old piglets which were fed with diets containing BP or BP plus YE.

Piglets which were fed with diet containing $1.0 \% \mathrm{BP}+1.0 \% \mathrm{YE}$ (from 36 to 49 days old) were observed to have better ADFI in the period from 50 to 60 days, in absolute values, as compared to the ones given the control diet containing $2.0 \% \mathrm{BP}(1.120 \mathrm{x}$ 1.070). Although the observed ADFI increase was not significant, it was enough to provide higher body weight, in absolute values, for piglets at 60 days of age.

A quadratic effect $(\mathrm{P}<0.01)$ was also found for YE levels on the ADG, which has improved up to the estimated level of $1.67 \%$ YE. Results obtained in this study differ from CARLSON et al. (2005), who reported no differences when evaluating the residual effect on ADG of 48 to 75-days old piglets, after they had been fed with diets containing YE $(0 ; 2.5 \%)$ from 34 to 47 day of age.

No effects were observed $(\mathrm{P}>0.10)$ on the piglets' ADG comparing control diet and 
Table 3 - Piglets performance fed diets with blood plasma and/or yeast extract from 36 to 49 -days and from 50 to 60-days old.

\begin{tabular}{|c|c|c|c|c|c|c|c|}
\hline \multirow{2}{*}{ Item } & \multicolumn{7}{|c|}{-Levels of plasma and yeast extract (\%)-- } \\
\hline & $2.0 \mathrm{BP}$ & $1.0 \mathrm{BP}+0.0 \mathrm{YE}$ & $1.0 \mathrm{BP}+1.0 \mathrm{YE}$ & $1.0 \mathrm{BP}+2.0 \mathrm{YE}$ & $1.0 \mathrm{BP}+3.0 \mathrm{YE}$ & Regression & CV $(\%)$ \\
\hline IBW (kg) & 8.79 & 8.91 & 8.77 & 8.74 & 8.32 & ns & 4.36 \\
\hline BW49 (kg) & 15.70 & 15.41 & 15.90 & 15.42 & 14.92 & ns & 5.19 \\
\hline ADFI $(g)$ & 726 & 689 & 728 & 686 & 683 & $\mathrm{~ns}$ & 8.35 \\
\hline $\mathrm{ADG}(\mathrm{g})$ & 493 & 464 & 509 & 477 & 471 & $\mathrm{~ns}$ & 9.50 \\
\hline FC & 1.47 & 1.48 & 1.43 & 1.44 & 1.45 & $\mathrm{~ns}$ & 5.64 \\
\hline & & & -------50 to & -days old------- & & & - \\
\hline FBW (kg) & 22.95 & 22.38 & 23.77 & 23.34 & 22.69 & $\mathrm{Q}^{1}$ & 6.38 \\
\hline ADFI (g) & 1.070 & 0.999 & 1.120 & 1.080 & 1.050 & $\mathrm{Q}^{2}$ & 8.58 \\
\hline $\mathrm{ADG}(\mathrm{g})$ & 658 & 634 & 715 & 719 & 670 & $\mathrm{Q}^{3}$ & 10.30 \\
\hline $\mathrm{FC}$ & $1.63^{\mathrm{a}}$ & $1.58^{\mathrm{a}}$ & $1.57^{\mathrm{a}}$ & $1.50^{\mathrm{b}}$ & $1.57^{\mathrm{a}}$ & ns & 5.87 \\
\hline
\end{tabular}

BP (blood plasma); YE (yeast extract); IBW (initial body weight); BW49 (body weight at 49 days); FBW (final body weight); ADFI (average daily feed intake); ADG (average daily gain); FC (feed conversion ratio); CV (coefficient of variation). Regression: Regression analysis between diets containing 0.0 to $3.0 \%$ yeast extract - ns (not significant); $\mathrm{Q}{ }^{1}{ }^{1} \mathrm{Quadradic}$ effect $(\mathrm{P}<0.06) \mathrm{Y}=22.46+1.58 \mathrm{X}-0.51 \mathrm{X}^{2}$ $\left(\mathrm{r}^{2}=0.89\right) ;{ }^{2} \mathrm{Quadradic}$ effect $(\mathrm{P}<0.03) \mathrm{Y}=1.006+0.122 \mathrm{X}-0.036 \mathrm{X}^{2}\left(\mathrm{r}^{2}=0.83\right) ;{ }^{3}$ Quadradic effect $(\mathrm{P}<0.01) \mathrm{Y}=0.635+0.109 \mathrm{X}-0.032 \mathrm{X}^{2}$ $\left(\mathrm{r}^{2}=0.99\right)$. a, b- Mean values of each YE level followed by different superscripts in the same row differ from the control diet, according to Dunnet's test.

diets containing different YE levels. Conversely, RIGUEIRA et al. (2013) observed higher ADG for piglets (7 to 63-days old) which received a diet containing BP plus YE, as compared to the ones fed with plasma (from 7 to 49 days of age).

Yeast extract levels did not influence $(\mathrm{P}>0.10)$ the animals' FC. This result was similar to RIGUEIRA et al. (2013) who reported no influences from YE on FC. However, in the present study the piglets which were fed with the diet containing $1.0 \%$ $\mathrm{BP}+2.0 \%$ YE were observed to have better FC $(\mathrm{P}<0.01)$ as compared to the ones given the control diet $(2.0 \% \mathrm{BP})$. Once the ADFI of piglets which received the control diet and the ones which were fed with diet containing $1.0 \mathrm{BP}+2.0 \% \mathrm{YE}$ was similar in absolute values (1070 x 1080), the improved FC that was observed for piglets fed with diet containing 1.0 $\mathrm{BP}+2.0 \%$ YE may be justified by the higher usage efficiency of nutrients in the diet, and consequently by their increased ADG, in absolute values (719 x 658).

Comparing the initial phase (from 36 to 49 days of age) and the phase which evaluated the residual effect (from 50 to 60 days of age), it was possible to observe that the differences regarding final weights, ADFI and ADG were higher in the residual period when compared to the initial period. In the initial period, the diet containing $1.0 \% \mathrm{BP}+1.0 \% \mathrm{YE}$ was observed to provide, in absolute values, higher weights, ADG, and ADFI at day 49, as compared to the diet containing $2.0 \% \mathrm{BP}$, which correspond respectively to $1.27,3.14$, and $0.27 \%$.
Likewise, when analyzing the residual effect, the diet containing $1.0 \% \mathrm{BP}+1.0 \% \mathrm{YE}$ was observed to provide additional $3.45,7.97$, and $4.46 \%$ to final weights, ADG, and ADFI, as compared to diet containing $2.0 \%$ BP. Those results showed that diets containing BP alone have a lower residual effect on performance as compared to the diets containing BP plus YE. That result is confirmed in the study by BARBOSA et al. (2007), who observed that BP only yields positive effects on the piglets' performances during the period in which it is being consumed. In turn, results from the studies by VAN DJIK et al. (2001) and TORRALARDONA et al. (2002) concluded that BP provides its maximum beneficial effect on piglets' performances during the first week post-weaning.

According to TOUCHETTE et al. (1996), the reduced performances of piglets in the residual period after BP is removed from their diets takes place due to the reduced ADFI, among other factors. That hypothesis is reinforced by the results from studies by JIANG et al. (2000), who reproduced the effect from the increased feed consumption that is provided by $\mathrm{BP}$ through the isolated inclusion of immunoglobulins in diets. These studies suggested that immunoglobulins may be the main fraction responsible for the improved performances of piglets.

Besides that, as diets had the same amounts of nutrients, benefits that were observed with YE may be related to factors that are present in that ingredient, which are not considered to be essential nutrients in diets formulation, such as nucleotides, non-essential amino 
acids, and inositol. Use of exogenous nucleotides leads to the prevalence of beneficial gut microbiota, such as bifidobacteria and lactobacilli, and smaller quantities of gram-negative ones (UAUY et al., 1994), and it plays an important role in the recovery of intestinal mucosa after animals go through to some kind of challenge.

\section{CONCLUSION}

As it provides a better residual effect, the inclusion of $1.67 \%$ yeast extract allow ED in 36 to 49 days old piglet diets, the replacement of $50 \%$ plasma, whose inclusion may be reduced from 2.0 to $1.0 \%$.

\section{BIOETHICS AND BIOSSECURITY COMMITTEE APPROVAL}

Approved by the ethics committee in the use of animals/ Universidade Federal de Viçosa (UFV), under protocol no. 19/2012.

\section{ACKNOWLEDGMENTS}

We would like to thank Conselho Nacional de Desenvolvimento Científico e Tecnológico (CNPq) for providing a research grant, and Alltech do Brasil for the financial support.

\section{REFERENCES}

BARBOSA, F.F. et al. Níveis de plasma sanguíneo em pó em dietas para leitões desmamados aos 21 dias de idade. Revista Brasileira de Zootecnia, v.36, p.1052-1060, 2007. Available from: <http:// dx.doi.org/10.1590/S1516-35982007000500010>. Accessed: Nov. 10, 2013. doi: 10.1590/S1516-35982007000500010.

CARLSON, M.S. et al. Effects of yeast extract versus animal plasma in weanling pig diets on growth performance and intestinal morphology. Journal of Swine Health and Production, v.13, p.204-209, 2005. Available from: <https:/www.aasv.org/shap/ issues/v13n4/v13n4p204.html>. Accessed: Nov. 10, 2013.

COFFEY, R.D.; CROMWELL, G.L. The impact of environment and antimicrobial agents on the growth response of early weaned pigs to spray-dried porcine plasma. Journal of Animal Science, v.73, p.2532-2539, 1995. Available from: <https:// dl.sciencesocieties.org/publications/jas/abstracts/73/9/2532>. Accessed: Nov. 10, 2013. doi: 1995.7392532x.

DE ANDRADE, C. et al. Levedura hidrolisada como fonte de nucleotídeos para leitões recém-desmamados. Revista Brasileira de Zootecnia, v.40, p.788-796, 2011. Available from: < http://www. sbz.org.br/revista/artigos/66138.pdf $>$. Accessed: Nov. 10, 2013.

FERREIRA, R.A. Maior produção com melhor ambiente para aves, suínos e bovinos. Viçosa: Aprenda Fácil, 2005. 371p.

FERREIRA, V.P.A. et al. Dietas para leitões em aleitamento e pós-desmame. Revista Brasileira de Zootecnia, v.30, p.753760, 2001. Available from: <http://dx.doi.org/10.1590/S151635982001000300021>. Accessed: Nov. 10, 2013. doi: 10.1590/ S1516-35982001000300021.
HU, L. et al. Effects of yeast-derived protein vs spray-dried porcine plasma supplementation on growth performance, metabolism and immune response of weanling piglets. Italian Journal of Animal Science, v. 13, p.163-168, 2014. Available from: <http:// dx.doi.org/10.4081/ijas.2014.3154>. Accessed: Jan. 10, 2015. doi: 10.4081/ijas.2014.3154.

JIANG, R. et al. Dietary plasma protein reduces small intestinal growth and lamina propria cell density in early weaned pigs. Journal of Nutrition, v.130, p.21-26, 2000. Available from: <http:// jn.nutrition.org/content/130/1/21.full>. Accessed: Nov. 10, 2013.

RIGUEIRA, L.C.M. et al. Effect of plasma and/or yeast extract on performance and intestinal morphology of piglets from 7 to 63 days of age. Revista Brasileira de Zootecnia, v.42, p.946503, 2013. Available from: <http://dx.doi.org/10.1590/S151635982013000700006>. Accessed: Jan. 20, 2015. doi: 10.1590/ S1516-35982013000700006.

ROSSI, P. et al. Nucleotídeos na nutrição animal. Revista Brasileira de Agrociência, v.13, p.5-12, 2007. Available from: $<$ http://www2.ufpel.edu.br/faem/agrociencia/v13n1/artigo01. htm>. Accessed: Nov. 10, 2013.

ROSTAGNO, H.S. et al. Tabelas brasileiras para aves e suínos: composição de alimentos e exigências nutricionais. Viçosa: UFV, 2005. 186p.

SOBESTIANSKY, J. et al. Manejo dos leitões desde o nascimento até o abate. Suinocultura intensiva: produção, manejo e saúde do rebanho. Brasília: EMBRAPA, 2001. Cap.7, p.135-161.

THANISSERY, R. et al. Evaluation of the efficacy of yeast extract in reducing intestinal Clostridium perfringens levels in broiler chickens. Poultry Science, v.89, p.2380-2388, 2010. Available from: <http://ps.oxfordjournals.org/content/89/11/2380.full $>$. Accessed: Nov. 10, 2013. doi: 10.3382/ps.2010-00879.

TORRALARDONA, D. et al. Use of spray dried animal plasma as an alternative to antimicrobial medication in weanling pigs. Animal Feed Science and Technology, v.99, p.119-129, 2002. Available from: <http://dx.doi.org/10.1016/S0377-8401(02)00072-X>. Accessed: Nov. 10, 2013. doi: 10.1016/S0377-8401(02)00072-X.

TOUCHETTE, K.J. et al. The effects of plasma, lactose and soil protein sources fed in a phase 1 diet on nursery performance. Journal of Animal Science, v.74, supl.1, p.170, 1996.

TRCKOVA, M. et al. The effects of live yeast Saccharomyces cerevisiae on postweaning diarrhea, immune response, and growth performance in weaned piglets. Journal of Animal Science, v.92, p.767-774, 2014. Available from: <https://www. animalsciencepublications.org/publications/jas/articles/92/2/76 7?highlight $=\&$ search-result $=1>$. Accessed: Jan. 20, 2015. doi: 10.2527/jas.2013-6793.

UAUY, R. et al. Role of nucleotides in intestinal development and repair: implications for infant nutrition. Journal of Nutrition, v.124, p.1436-1441, 1994. Available from: <http://jn.nutrition.org/ content/124/8_Suppl/1436S.full.pdf+html>.Accessed: Nov. 10, 2013.

VAN DIJK, A.J. et al. Growth performance of weanling pigs fed spray-dried animal plasma: a review. Livestock Production Science, v.68, p.263-274, 2001. Available from: <http://dx.doi. org/10.1016/S0301-6226(00)00229-3>. Accessed: Nov. 10, 2013. doi: 10.1016/S0301-6226(00)00229-3. 